\title{
PRELIMINARY REPORT ON THE ABSENCE OF TOXICITY OF FRUIT PULP OF PALMYRAH (BORASSUS FLABELLIFER L.) IN ICR MICE
}

\author{
INOKA ULUWADUGE ${ }^{1^{*}}$, M.I.THABREW ${ }^{1}$ and E.R.JANSZ ${ }^{2}$ \\ ${ }_{1}$ Department of Biochemistry \& Clinical Chemistry, Faculty of Medicine, University of Kelaniya, Thallagolla \\ Rd., Ragama. \\ ${ }^{2}$ Department of Biochemistry, Faculty of Medical Sciences, University of Sri Jayewardenapura, Nugegoda.
}

\begin{abstract}
Palmyrah (Borassus flabellifer L.) flour prepared from the seed shoot has been previously reported to cause hepatotoxic, neurotoxic and other toxic effects. Although palmyrah fruit pulp (PFP) is also consumed in Sri Lanka, no toxicity studies have been done. Short and long term toxicity studies were therefore conducted with PFP by administration of $10 \%$ or $50 \%$ PFP (dry basis) incorporated into WHO standard feed (part of the maize being substituted with PFP) compared with a control group of ICR mice, fed the WHO standard feed $(n=7$ in each group, age 6 weeks, weight 36 $44 \mathrm{~g}$ ), for 7 or 30 days. In both studies the effect of $10 \%$ or $50 \%$ PFP feed on liver and kidney function and haematological parameters (haemoglobin concentration, packed cell volume, white blood cell count and red blood cell count) were determined. Liver function was assessed by estimation of serum levels of alanine transaminase, aspartate transaminase and alkaline phosphatase. Renal toxicity was assessed by estimation of serum creatinine levels. In the long term toxicity study, effect of PFP on histology of main body organs (heart, lung, liver, kidney and intestine) were also assessed by microscopic examination of haematoxylin / eosin stained sections of these organs. Results of both the short term and long term toxicity studies demonstrated that PFP at the $10 \%$ or $50 \%$ level did not have any significant effect on kidney or liver function nor on the haematological parameters under study and on the histology of major body organs in ICR mice. In all studies, neurotoxicity was assessed by comparing the behaviour of the test group with the control group. No behavioural changes or spasms were observed in the test groups of mice fed with the feed containing $10 \%$ or $50 \%$ PFP. The overall results suggest that PFP even at the $50 \%$ level in the standard feed probably does not produce any toxic effects in ICR mice.
\end{abstract}

Key words: Borassus flabellifer, Palmyrah fruit pulp, toxicity.

\section{INTRODUCTION}

Palmyrah (Borassus flabellifer L. , Family; Arecaceae, Sub family; Boracidae) fruit pulp (PFP) contains several bioactive flabelliferins. ${ }^{1,2}$ Flabelliferins are a family of steroidal saponins complexed with carbohydrate moieties. ${ }^{3}$ Of the flabelliferins isolated so far from PFP, the tetraglycoside F-II has been shown to inhibit glucose uptake $e^{4}$ and cause weight $\operatorname{loss}^{4,5}$ in ICR mice, while the triglycoside $\mathrm{Fb}$ has been shown to possess anti-microbial activity. ${ }^{1}$
Palmyrah flour (odiyal) prepared from the seed shoot shows neurotoxic, ${ }^{6,7}$ hepatotoxic, ${ }^{6}$ immunotoxic $^{8-12}$ and other biological activities such as mutagenic, ${ }^{13}$ and clastogenic ${ }^{14}$ effects in mice, when $50 \%$ of the normal feed has been substituted with palmyrah flour. Furthermore, feeding of diets containing palmyrah flour to lactating rats resulted in hepatic, pulmonary and renal lesions and subcutaneous haemorhages in the suckling rats. ${ }^{15}$ Although $\mathrm{PFP}$ is not consumed widely as a sweet meat at present, the Palmyrah Development Board (PDB), Sri Lanka intends popularizing other products from PFP (eg: beverages) which will increase its consumption. ${ }^{16}$ No control studies have been carried out to date to investigate possible toxic effects that PFP consumption may produce. Therefore, the study of the potential toxic effects of PFP becomes important.

The objective of this study was to test for toxic effects of PFP in ICR mice, when substituted in standard feed as follows.

\section{I. at a $50 \%$ level \\ II. at a $10 \%$ level}

Toxic effects were assessed by (a) estimation of serum enzyme levels of aspartate transaminase, alanine transaminase and alkaline phosphatase (b) measurements of serum creatinine level (c) effects on haematological parameters (packed cell volume, red blood cell count, white blood cell count and haemoglobin concentration) and (d) histopathological changes of major body organs (liver, kidney, heart, lung and intestine) while recording feed intake, weight gain and observing for behavioural changes and other toxic symptoms.

\section{METHODS AND MATERIALS}

Palmyrah fruit pulp: PFP was obtained from fruits originating from Kalpitiya in the North- 
West of Sri Lanka. The fruit pulp was extracted manually as previously described. ${ }^{5}$

Animal Model: Inbred genetically homogeneous, Institute of Cancer Research (ICR) mice ( age 6-8 weeks, weight $35-42 \mathrm{~g}$ ) were obtained from the MRI (Medical Research Institute), Colombo and experiments were conducted at the animal house, University of Sri Jayewardenepura.

Male ICR mice were used for each variable ( $n=7$ in each group). The control animals were fed with the standard rat and mouse breeding feed prepared by the Medical Research Institute, according to WHO rat and mouse breeding feed formula. ${ }^{17}$ The test animals were fed with the $10 \%$ or 50\% PFP incorporated in the above WHO standard feed. The $10 \%$ test feed was prepared by replacing a part (one third) of the maize in the WHO standard feed with PFP ( on a dry weight basis). The test and control diets were isocaloric. This was not possible for the 50\% PFP incorporated feed where calories were higher in the test feed.

Serum enzyme and creatinine assays: At the end of 7 days (short term toxicity studies) or 30 days (long term toxicity studies) of feeding with the control and PFP containing feed, the animals were anaesthetised with diethyl ether and blood samples $(1 \mathrm{ml})$ collected by cardiac puncture. The blood samples were centrifuged at $900 \mathrm{~g}$ for 10 minutes, and the serum was separated and the activities of alanine transaminase ${ }^{18}$, aspartate transaminase ${ }^{18}$, alkaline phosphatase ${ }^{19}$ and creatinine ${ }^{20}$ were determined by standard colorimetric methods using commercially available diagnostic kits (Randox Laboratory, UK).

Haematological parameters: At the end of the short term (7 days) and long term (30 days) of feeding with the PFP containing feed, the animals were anesthetised with diethyl ether and the blood samples (1ml) collected into clean dry sample bottles containing anticoagulant EDTA, by cardiac puncture. The haematological parameters (packed cell volume, red blood cell count, white blood cell count and haemoglobin concentration) in the blood samples were assessed by the methods described by International Committee for Standarization in haematology ${ }^{21}$ and compared with corresponding values in control animals.

Histopathology ${ }^{22}$ : The animals were sacrificed and the liver, kidney, heart, lung and intestine were removed and fixed in $10 \%$ formol-saline. The sections were processed for sectioning at $5 \mathrm{~mm}$ thickness and stained with haematoxylin and eosin. The sections were viewed on a light microscope (Olympus $\mathrm{CH} 30$ ) at magnifications of 40 and 100.

Statistical Analysis: The results were expressed as Mean \pm Standard Error of mean (SEM). The significance of difference in the parameters tested between test and control groups were analyzed by Student's t test. Differences were considered significant if $\mathrm{p}<0.05$.

Table 1: Serum level of alanine transaminase (ALT), aspartate transaminase (AST), alkaline phosphatase (ALP), creatinine, and haematological parameters on administration of $10 \%$ PFP containing feed for 1 week. (short term effects)

\begin{tabular}{lccc}
\hline & \multicolumn{3}{c}{ Group } \\
\cline { 2 - 4 } Parameter & Control & Test & p value \\
\hline $\mathrm{AST}(\mathrm{U} / \mathrm{L})$ & $27.3 \pm 1.09$ & $29.8 \pm 2.94$ & 0.44 \\
$\mathrm{ALT}(\mathrm{U} / \mathrm{L}$ & $19.3 \pm 2.91$ & $13.4 \pm 0.98$ & 0.062 \\
$\mathrm{ALP}(\mathrm{U} / \mathrm{L})$ & $104.6 \pm 5.16$ & $93.7 \pm 3.58$ & 0.46 \\
$\mathrm{Creatinine}(\mu \mathrm{mol} / \mathrm{L})$ & $25.8 \pm 0.56$ & $23.3 \pm 0.67$ & 0.25 \\
$\mathrm{PCV} /$ & $41.5 \pm 0.72$ & $41 \pm 0.73$ & 0.65 \\
$\mathrm{Hb} \mathrm{mg/dl}$ & $13.5 \pm 0.1$ & $13.4 \pm 0.13$ & 0.73 \\
$\mathrm{WBC} / \mathrm{mm}^{3}$ & $4480 \pm 10.8$ & $4468 \pm 9.2$ & 0.52 \\
$\mathrm{RBC} / \mathrm{mm}^{3}$ & $550 \times 10^{4} \pm 10.6$ & $560 \times 10^{4} \pm 12.8$ & 0.51 \\
\hline
\end{tabular}

Results are expressed as Mean $\pm \operatorname{SEM},(n=7)$. 


\section{RESULTS}

Short term toxicity studies

At $10 \%$ feed ( 7 days)

As evident from Table 1, there was no evidence of toxicity as judged by serum enzymology (alanine transaminase, aspartate transaminase, alkaline phosphatase), serum creatinine and haematological parameters. No neurotoxic symptoms such as hyper-excitability, salivation, muscle tremors, piloerection, changes in locomotor activity, changes in posture, ataxia and loss of reflexes could also be observed.

\section{Long term toxicity studies}

At $10 \%$ or $50 \%$ feed (30 days)

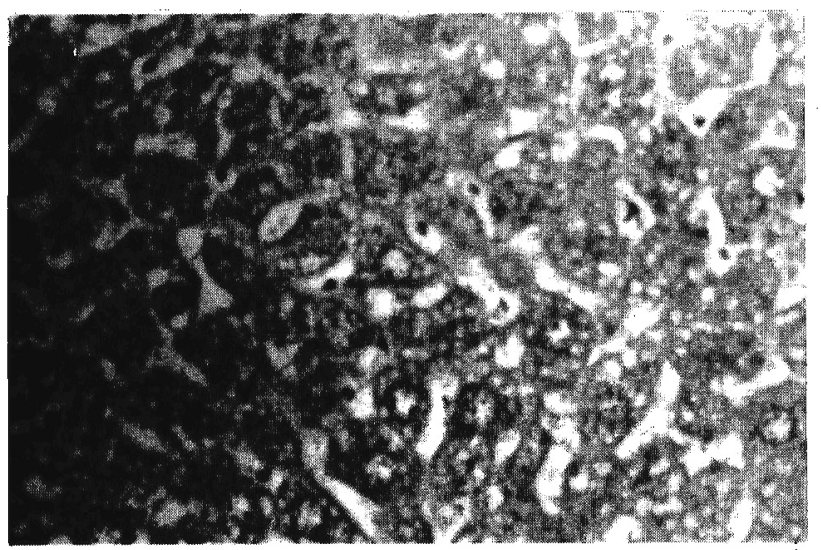

a

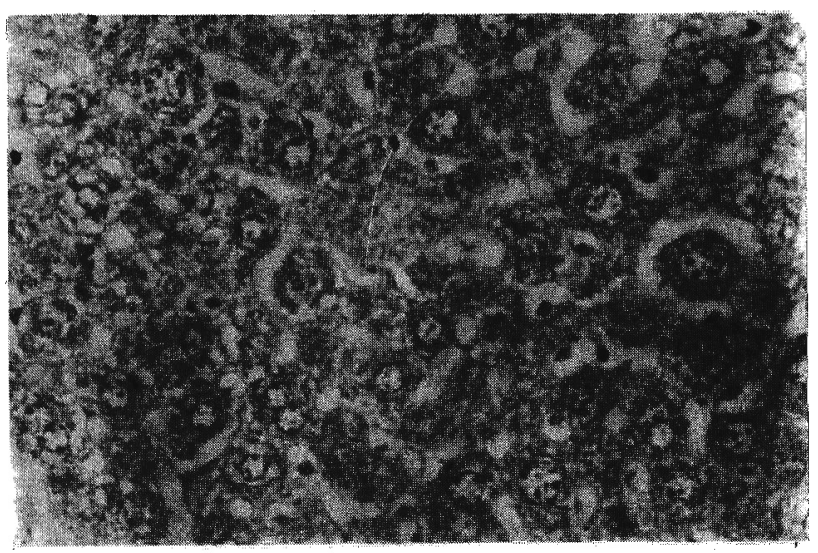

b

Figure 1: Photomicrographs of (a) test (10\% PFP containing feed) and (b) control, mice livers 30 days after feeding . H\&E, $\times 100$.

Results given in table 2 show that neither the serum enzyme levels and creatinine nor the haematological parameters were elevated in the animals receiving feed containing PFP at $10 \%$ or $50 \%$ level for 30 days when compared with the control animals. No neurotoxic symptoms could also be observed in the test animals. No histopathological changes were observed in haematoxylin and eosin stained sections of the liver, kidney, lung, heart and intestine of test animals when compared with those from control animals. Since the predominant toxicity of the flour is on the liver ${ }^{6}$ photomicrograph sections of mouse livers in control and test animals fed PFP containing feed (at $10 \%$ or $50 \%$ level) are shown in Figures $1 \& 2$.

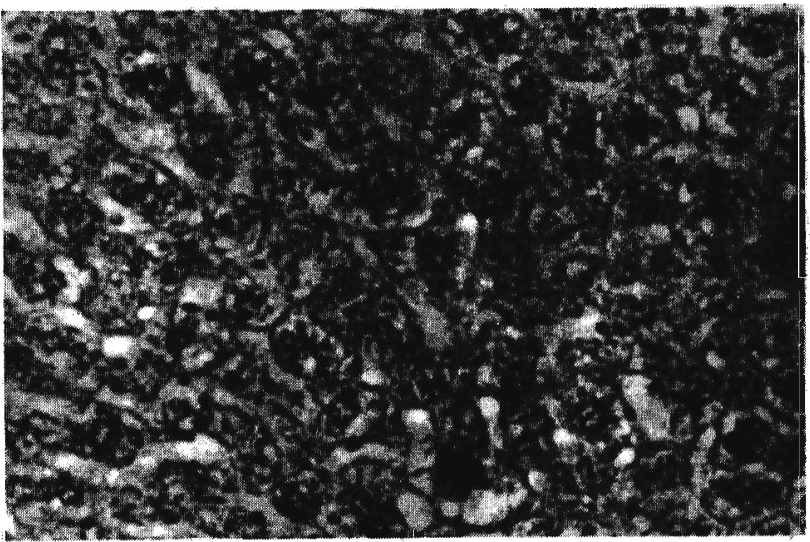

c

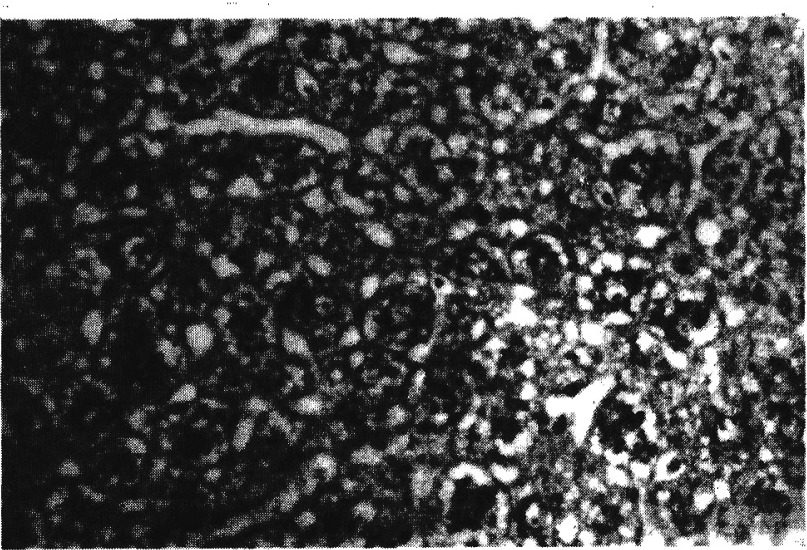

d

Figure 2: Photomicrographs of (c) test (50\% PFP containing feed) and (d) control, mice livers 30 days after feeding. H\&E, $\times 100$.

\section{DISCUSSION}

Results of the present investigation demonstrate that short term (7days) or long term (30 days) feeding of PFP incorporated feed to mice did not produce any significant toxic effects as assessed 
Table 2: Serum level of alanine transaminase (ALT), aspartate transaminase (AST), alkaline phosphatase (ALP), creatinine, and haematological parameters on administration of $10 \%$ or $50 \%$ PFP containing feed for 1 month.( Log term effects)

\begin{tabular}{lllll}
\hline & \multicolumn{3}{c}{ Group } \\
\cline { 2 - 5 } Parameters & Control & \multicolumn{1}{c}{ Test(10\% PFP) } & Control & Test(50\% PFP) \\
\hline AST (U/L) & $35 \pm 3.5$ & $35.6 \pm 2.5 \quad(\mathrm{p}=0.84)$ & $38 \pm 4.2$ & $37 \pm 3.5(\mathrm{p}=0.68)$ \\
ALT (U/L & $14.3 \pm 1.6$ & $13.8 \pm 1.9(\mathrm{p}=0.76)$ & $14.9 \pm 2.5$ & $15.2 \pm 2.8(\mathrm{p}=0.87)$ \\
ALP (U/L) & $112.5 \pm 5.5$ & $113.5 \pm 3.8(\mathrm{p}=0.91)$ & $106.5 \pm 6.5$ & $107.2 \pm 5.2(\mathrm{p}=0.75)$ \\
Creatinine $(\mu \mathrm{mol} / \mathrm{L})$ & $23.9 \pm 1.8$ & $24.5 \pm 1.2(\mathrm{p}=0.67)$ & $24.2 \pm 1.6$ & $23 \pm 2.0(\mathrm{p}=0.78)$ \\
PCV\% & $41.5 \pm 0.9$ & $41.0 \pm 0.73(\mathrm{p}=0.85)$ & $41.2 \pm 1.6$ & $40.3 \pm 1.2(\mathrm{p}=0.74)$ \\
$\mathrm{Hb} \mathrm{mg} / \mathrm{dl}$ & $14.0 \pm 0.25$ & $13.4 \pm 0.13(\mathrm{p}=0.66)$ & $13.6 \pm 0.7$ & $13.5 \pm 0.9(\mathrm{p}=0.59)$ \\
WBC / mm & $4490 \pm 10.6$ & $4480 \pm 13.2(\mathrm{p}=89)$ & $4488 \pm 15.2$ & $4480 \pm 10.8 \mathrm{p}=0.72)$ \\
$\mathrm{RBC} / \mathrm{mm}^{3}$ & $578 \times 10^{4} \pm 10.5$ & $585 \times 10^{4} \pm 13.2(\mathrm{p}=0.56)$ & $568 \times 10^{4} \pm 10.6$ & $560 \times 10^{4} \pm 10(\mathrm{p}=0.78)$ \\
\hline
\end{tabular}

Results are expressed as Mean $\pm \operatorname{SEM},(n=7)$.

by its effects on liver and kidney function, haematologicl parameters and histology of major body organs. This is in contrast to what has been observed in a previous investigation with palmyrah flour. ${ }^{6,7}$ In this study administration of palmyrah flour containing feed (at a $50 \%$ level) to mice resulted in neurotoxic symptoms in 4-6 days. This was not observed when mice were fed on 50 $\%$ PFP containing feed even for 30 days. Palmyrah fruit pulp therefore appears to be non-toxic at least up to a $50 \%$ level of substitution.

Food intake and weight gain of the test animals were normal over a period of one month at a $10 \%$ level and $50 \%$ level further confirming the probable absence of toxic principals in PFP similar to those reported in palmyrah flour.

\section{Acknowledgement}

The authors thank NSF grant No.RG/2001/M/01, IPICS SRI: 07 for special chemicals and Dr. Kamani Samarasinghe, Dept of Pathology, Univ. of Sri Jayewardenepura for histopathological studies.

\section{References}

1. Nikawala J.K., Jansz E.R., Wijeyaratne S.C. \& Jayasekera S. (1998). Flabelliferins, steroidal saponins from palmyrah (Borassus flabellifer L.) fruit pulp. II Preliminary studies on effect on yeast and selected bacteria. Journal of the National Science Council 25:141-150.
2. Nikawala J.K., Jansz E.R., Abeysekera A.M., Wijeyaratne S.C., \& Gamage U.C. (1998). Studies on chemistry and bioactivity of the flabelliferins, steroidal saponins from palmyrah (Borassus flabellifer) fruit pulp. Chemistry in Sri Lanka 15:6-7.

3. Jansz E.R., Nikawala J.K., Gunaratne M.J. \& Thievendirarajah K. (1994). Studies on the bitter principle and debittering of palmyrah fruit pulp. Journal of the Science of Food and Agriculture 65:185-109.

4. Uluwaduge I., Thabrew M.I. \& Jansz E.R. (2003). Biochemical basis for the reduced weight gain mediated by palmyrah (Borassus flabellifer) fruit pulp. Annual sessions. Faculty of Medical Sciences.University of Sri Jayewardenenepura.

5. Ariyasena D.D., Jansz E.R., Jayasekera S. \& Abeysekara A.M. (2001). Effect of palmyrah (Borassus flabellifer L.) fruit pulp on weight gain of mice. Vidyodaya Journal of Science 9:97-103.

6. Arseculeratne S.N., Panabokke R.G., Tennekoon G. \& Bandunatha C.H.S.R. (1971). Toxic effects of Borassus flabellifer L. (palmyrah palm) flour in rats. British Journal of Experimental Pathology 52:524537. 
7. Grieg J.B., Kay S.J.E. \& Bennets R.J. (1980). A Toxin from palmyrah palm, (Borassus flabellifer L.); Partial purification and effects in rats. Food and Cosmetics Toxicology 18:483-488.

8. Panabokke R.G. \& Arseculeratne S.N. (1977). Malignant lymphomas in rats after prolonged feeding with palmyrah (Borassus flabellifer L.) flour. Proceedings of the Sri Lanka Association for the Advancement of Science 35:5.

9. Arseculeratne S.N. (1991). Malignant lymphomas in rats after prolonged feeding with palmyrah (Borassus flabellifer). Ceylon Medical Journal 36: 137-141.

10. Arseculeratne S.N., Sirisinha S., Charupatana K. \& Kangwangpong D. (1981). Immunological alterations in rats fed with flour from the palmyrah palm. Proceedings of the Society of Experimental Biology and Medicine 168:356-360.

11. Devi S., Arseculeratne S.N., Pathmanathan R., Mackenzie I.F.C. \& Pong T. (1985). Suppression of cell mediated immunity following oral feeding of mice with palmyrah (Borassus flabellifer L.) flour. Australian Journal of Experimental Biological and Medical Science 63:371-379.

12. Arseculeratne S.N. \& Panabokke R.G. (1983). Studies on the toxicology of the palmyrah palm (Borassus flabellifer L.) Part III. Development of malignant lymphomas in rats after prolonged feeding of palmyrah flour. Journal of the National Science Council of Sri Lanka 11(1): 11-23.

13. Anderson P.H. \& Poulsen E. (1985). Mutagenicity of flour from palmyrah palm (Borassus flabellifer L.) in Salmonella typhimurium and Escherichia coli. Cancer Letters 26: 118-119.
14. Kangwangpong D., Arseculeratne S.N. \& Sirisinha S. (1981). Clastogenic effect of aqueous extracts of palmyrah flour on human blood lymphocytes. Mutation Research 89: 63-68.

15. Arseculeratne S.N., Gunatilleke A.A.L. \& Panabokke R.G. (1982). Studies on the toxicity of palmyrah palm (Borassus flabellifer L.) Part II. Milk transfer of toxicity to suckling rats. Journal of the National Science Council of Sri Lanka 10: 277-282

16. Balasubramanium K., Jansz E.R.\& Ariyasena D.D. (1999). "Palmyrah" -a monograph. International Program In Chemical Sciences (IPICS), Uppsala, Sweden. pp 1-39.

17. Sabourdy M. A. (1998). Breeding and care of laboratory animals. WHO/Lab/ 88(1): 1-45.

18. Reitman S. \& Frankel S. (1957). A colourimetric method for the determination of serum glutamate oxaloacetic acid and pyruvic acid transaminases. American Journal of Clinical Pathology 28: 56-63.

19. King E.J., Harkwood G.A.D., Derty G.E. \& Beally D. (1942). Microbiochemical methods of blood analysis. Lancet 1: 208-210.

20. Varley H.(1988). Determination of serum creatinine In: Practical Biochemistry. CBS Publishers and Distributors, India. pp 197199.

21. Manual of Procedures in Haematology. (1994). State Printing Corporation, Colombo. pp 1-39.

22. Manual of Procedures in Histopathology (1994). State Printing Corporation, Colombo. pp 10-68. 